\title{
PrePaRING SUPPORT FOR LOCAL COMMUNITIES TO DEVELOP, IMPLEMENT AND EVALUATE PSYCHOACTIVE SUBSTANCE USE PREVENTION PROGRAMMES
}

PRZYGoTOWANIE WSPARCIA DLA

SPOKECZNOŚCI LOKALNYCH W SPRAWIE

OPRACOWANIA, WPROWADZENIA I EWALUACJI

PROGRAMÓW PROFILAKTYKI DOTYCZĄCYCH UŻYWANIA SUBSTANCJI PSYCHOAKTYWNYCH

\author{
Janusz Sierosławski \\ Institute of Psychiatry and Neurology, Department of Studies on Alcoholism and Drug Dependence, Warsaw, Poland
}

Instytut Psychiatrii i Neurologii, Zakład Badań nad Alkoholizmem i Toksykomaniami, Warszawa, Polska

Alcohol Drug Addict 2017; 30 (2): 155-159

DOI: https://doi.org/10.5114/ain.2017.70291

Both in Poland and in an ever-growing number of countries, the significant role of the local community in the prevention of problems related to alcohol and other psychoactive substances use is being noticed. In Poland, we have a relatively long tradition of activity at the local level going back from before the Second World War and continuing after October 1956. In the 1990s, the first attempts at setting up structured local programmes were made, and in the first decade of this century, local programmes became a general, sustainable and legally sanctioned element of the realisation of tasks concerning the prevention of psychoactive substance-use related problems. The National Bureau
Zarówno w Polsce, jak i w coraz większej liczbie krajów dostrzega się doniosłą rolę, jaką może odegrać społeczność lokalna w zapobieganiu problemom związanym z piciem alkoholu i używaniem innych substancji psychoaktywnych. W Polsce mamy dość długą tradycję działań na poziomie lokalnym, sięgającą okresu przed drugą wojną światową, a kontynuowaną po październiku 1956 roku. $\mathrm{W}$ latach 90. minionego stulecia podjęto pierwsze próby budowania ustrukturyzowanych programów lokalnych, a w pierwszej dekadzie obecnego stulecia lokalne programy stały się powszechnym, trwałym i usankcjonowanym prawnie elementem realizacji zadań w zakresie profilaktyki problemów związanych

Correspondence to/Adres do korespondencji: Janusz Sierosławski, Instytut Psychiatrii i Neurologii, Zakład Badań nad Alkoholizmem

i Toksykomaniami, Sobieskiego 9, 02-957 Warszawa, Polska phone: +48 224582 739, e-mail: sierosla@ipin.edu.pl

Authors' contribution/Wkład pracy autorów

No ghostwriting declared./Nie występuje zjawisko ghostwriting

Submitted/Otrzymano: 25.06.2017 • Accepted/Przyjęto do druku: 04.07.2017 
for Drug Prevention and the State Agency for the Prevention of Alcohol-Related Problems support local initiatives creating platforms for experience exchange in this matter for municipalities and communities in our country. The seminar organised on the $5^{\text {th }}$ and $6^{\text {th }}$ September 2016 in Warsaw was an initiative to widen the scope of experience exchange at an international level. The initiative in this enterprise was taken by the Alcohol and Substance Abuse Expert Group of The Northern Dimension Partnership in Public Health and Social Well-being (ASA NDPHS), with financial support from the Norwegian Bilateral Relation Fund within Programme PL13 "Reducing social inequalities in health". The meeting was attended by representatives from Norway, Estonia, Lithuania, Sweden and Poland, both from central institutions responsible for psychoactive substance policy and their local-level equivalents.

The aim of the seminar was not only the exchange of experiences concerning the prevention of psychoactive substance use but also the preparation of an outline of the concept for common activities. It was initially established that the following cities would participate in the forthcoming project: Pärnu (Estonia), Klaipèda (Lithuania), Kalmar (Sweden), Drammen (Norway) and Starachowice (Poland), hence their representatives attendance as guests at the seminar.

The discussion starting point were presentations of national legal frameworks and organisational structures responsible for the prevention with particular focus on the place and role of local communities. All the countries whose representatives participated in the seminar have a similarly developed structure with a leading role played by respective ministries of health. The dominating approach to the problem of alcoholism and drugs is the concept of public health. In all these countries, at least a part of the responsibility for prevention is in the hands of local authorities. Differences are in details, e.g. in methods of financing. In Poland, prevention of alcohol and drug related problems is financed with local funds raised on alcoholic beverages licensing fees. Meanwhile, in Norway, the funds are transferred from the central level to the local and distributed by the Norwegian Directorate of Health - the state executive agency for public health. In Lithuania, a National Public Health Promotion Fund directed by the ministry of health has been z używaniem substancji psychoaktywnych. Krajowe Biuro ds. Przeciwdziałania Narkomanii oraz Państwowa Agencja Rozwiązywania Problemów Alkoholowych wspierają inicjatywy lokalne, tworząc platformy wymiany doświadczeń $\mathrm{w}$ tej dziedzinie dla miast i gmin naszego kraju. Próbą wyjścia z tą problematyką na forum międzynarodowe, $z$ intencją rozszerzenia zakresu wymiany doświadczeń, było seminarium zorganizowane w Warszawie 5-6 września 2016 roku. Z inicjatywą takiego przedsięwzięcia wyszła Grupa Ekspertów ds. Nadużywania Substancji Psychoaktywnych Partnerstwa Wymiaru Północnego ds. Zdrowia i Dobrostanu Społecznego, a finansowego wsparcia udzielił Norweski Fundusz Współpracy Dwustronnej w ramach Programu PL13 „Ograniczanie społecznych nierówności w zdrowiu”. W spotkaniu uczestniczyli przedstawiciele Norwegii, Estonii, Litwy, Szwecji oraz Polski - zarówno z instytucji centralnych odpowiedzialnych za politykę wobec substancji psychoaktywnych, jak i ze szczebla lokalnego.

Celem seminarium była nie tylko wymiana doświadczeń dotyczących profilaktyki używania substancji psychoaktywnych, lecz także przygotowanie zarysu koncepcji wspólnych działań. Wstępnie ustalono, że w przyszłym projekcie będą uczestniczyć następujące miasta: Pärnu (Estonia), Klaipèda (Litwa), Kalmar (Szwecja), Drammen (Norwegia), Starachowice (Polska), dlatego ich przedstawiciele zostali zaproszeni na seminarium.

Punktem wyjścia dyskusji były prezentacje krajowych ram prawnych i struktur organizacyjnych odpowiedzialnych za profilaktykę, ze szczególnym uwzględnieniem miejsca i roli społeczności lokalnych. Wszystkie kraje, których przedstawiciele uczestniczyli w seminarium, mają podobnie rozbudowane struktury z wiodącą rolą odgrywaną przez ministerstwo zdrowia. Dominującym podejściem do problemu alkoholu i narkotyków jest koncept zdrowia publicznego. We wszystkich tych krajach przynajmniej część odpowiedzialności za profilaktykę spoczywa na władzach lokalnych. Różnice tkwią w szczegółach, np. sposobach finansowania. W Polsce profilaktyka problemów związanych $\mathrm{z}$ alkoholem i narkotykami jest finansowana $z$ funduszy lokalnych pochodzących z opłat za koncesje na sprzedaż napojów alkoholowych. W Norwegii natomiast fundusze przekazywane są z poziomu centralnego na poziom lokalny, rozdziela je Dyrektoriat Zdrowia - rządowa agencja wykonawcza w obszarze zdrowia publicznego. Na Litwie utworzono fundusz promocji zdrowia publicznego, którym zarządza ministerstwo zdrowia. 
established. One of the priorities set for 2016 is the matter of alcohol problem prevention together with mental health disorder prevention including suicide and the promotion of healthy lifestyles. The fund also supports the realisation of local initiatives. Both in Norway and Estonia, guidelines were established for local authority realisation of prevention activities.

A new public health act came into force in Norway in 2012 as part of the reform of health policy. The aim of the reform was to strengthen the promotion of health and early intervention thereby ensuring conditions for sustainable development. The concept of public health, which forms the basic assumption of the legislation, accepts common responsibility for the health of citizens not only at ministerial level but also at that of civil society and business. Legal frameworks were established obliging government to take into consideration the influence of any social or economic decision on public health on the assumption that health is one of the highest values. Study of the consequences of each decision on the state of public health is required. The legislation also regulates matters of local authority participation in the realisation of health policy, vesting it with a significant portion of responsibility and regulating its relations with the central level.

The basic principles guiding policy in the Norwegian public health legislation are care for social health capital, taking into account health considerations in all political decision-making, contributing to sustainable development of the country, preventing harm to health and general participation in the realisation of health policy.

In the above-mentioned countries, preventative measures are being taken at the local level concerning the use of psychoactive substances. These are also embedded in structures in the form of programmes. In Norway and Sweden, local programmes are built on the basis of problem diagnosis. Great emphasis is placed on monitoring conducted at the local level with the support of researchers and experts of the central level. Central institutions supply some of the data collected at central level following disaggregation to the local level. Monitoring data serve to evaluate process and the effects of programme realisation. It has also been possible to introduce a system of this kind in certain towns in Poland. Lithuania and Estonia are less advanced in the realisation of this approach.
Wśród priorytetów na 2016 rok znalazła się kwestia zapobiegania problemom alkoholowym, obok profilaktyki zaburzeń zdrowia psychicznego, w tym samobójstw, oraz promocji zdrowego stylu życia. Fundusz ten wspiera także realizację inicjatyw lokalnych. Zarówno w Norwegii, jak i w Estonii opracowano wytyczne dla władz lokalnych dla realizacji działań w zakresie profilaktyki.

W Norwegii w 2012 roku w ramach reformy polityki zdrowotnej uchwalono nową ustawę o zdrowiu publicznym. Celem reformy było wzmocnienie promocji zdrowia oraz wczesnej interwencji, a poprzez to zapewnienie warunków zrównoważonego rozwoju. Koncepcja zdrowia publicznego, która legła u podstaw ustawy, zakłada przyjęcie wspólnej odpowiedzialności za zdrowie obywateli nie tylko przez resorty, lecz także przez społeczeństwo obywatelskie czy biznes. Przyjmując, że zdrowie jest jedną z najwyższych wartości, tworzy się ramy prawne zobowiązujące władze, aby przy podejmowaniu decyzji społecznych czy gospodarczych uwzględniały ich wpływ na politykę zdrowotną. Wymaga się badania konsekwencji każdej z nich dla stanu zdrowia społeczeństwa. Ustawa porządkuje również kwestie uczestnictwa władz lokalnych w realizacji polityki zdrowotnej, nakładając na nie znaczą część odpowiedzialności oraz regulując ich relacje ze szczeblem centralnym.

Podstawowe zasady, jakie ma realizować norweska ustawa o zdrowiu publicznym to: dbanie o kapitał zdrowotny społeczeństwa, uwzględnianie kwestii zdrowia we wszystkich decyzjach politycznych, przyczynianie się do zrównoważonego rozwoju kraju, zapobieganie szkodom zdrowotnym oraz powszechne uczestnictwo w realizacji polityki zdrowotnej.

W wymienionych wyżej krajach prowadzi się działania zapobiegawcze dotyczące używania substancji psychoaktywnych na poziomie lokalnym. Wszędzie też są one ustrukturyzowane $\mathrm{w}$ postaci programów. W Norwegii i Szwecji lokalne programy budowane są na podstawie diagnozy problemu; kładzie się tam duży nacisk na monitoring prowadzony na poziomie lokalnym, przy wsparciu badaczy i ekspertów z poziomu centralnego. Instytucje centralne dostarczają też organom lokalnym część danych zbieranych centralnie po zdezagregowaniu na poziom lokalny. Dane z monitoringu służą do ewaluacji procesu i efektów realizacji programów. W Polsce w niektórych miastach także udało się wdrożyć podobny system. Litwa i Estonia są mniej zaawansowane $\mathrm{w}$ realizacji takiego podejścia. 
The Swedish representatives presented a pilot project entitled "Alcohol and drug prevention among youth in the Baltic Sea Region" realised in the Swedish town of Nynäshamn, Klaipeda in Lithuania, Drammen in Norway and Bagrationovsk in Russia under the auspices of ASA NDPHS. Its aim was to limit risk and harmful drinking and the use of other psychoactive substances by the youth. The realisation of the project was supposed to contribute to the strengthening of prevention infrastructure in the cities through assessment of needs and preventive potential, the development of longterm strategy and evaluation schemes. A large role was played by the preparation of instruments of monitoring that is supposed to supply data for the evaluation of changing needs and the effects of preventive strategy realisation. This is why it was essential to ensure researchers support. The experiences gained from this project make up a good starting point for consideration of a concept of common action in the local communities of the countries participating in the seminar.

The concept of common activities at the local level developed at the seminar:

- to develop standardised comparative survey on community readiness for alcohol and other drugs preventive activities,

- to develop a standardised comparative alcohol and drug survey for young people and young adults,

- to develop tools for more informed and evidence based policy making to reduce alcohol's and other drugs health and economic burden,

- to strengthen the capacity of local administration, public health structures and youth organisations to develop and implement effective and sustainable preventive work,

- to strengthen the capacity of the local institutions in usage of data sources to set up goals, target oriented services and to measure changes in the alcohol and drug situation,

- to build up the inter-sectorial cooperation for effective and efficient implementation of prevention activities on the local municipality level,

- to develop the network of the public health centres of the local municipalities in the Northern Dimension Region and increase regional cooperation in alcohol and other drugs prevention activities,

- to develop a report presenting an overview of individual country profiles.
Przedstawiciele Szwecji zaprezentowali pilotażowy projekt „Zapobieganie używaniu alkoholu i narkotyków przez młodzież w regionie Morza Bałtyckiego" zrealizowany w miastach Szwecji (Nynäshamn), Litwy (Klaipeda), Norwegii (Drammen) i Rosji (Bagrationovsk) pod auspicjami ASA NDPHS. Jego celem było ograniczenie ryzykownego i szkodliwego picia alkoholu oraz używania innych substancji psychoaktywnych przez młodzież. Realizacja projektu miała przyczynić się do wzmocnienia infrastruktury profilaktycznej w miastach poprzez ocenę potrzeb i potencjału profilaktycznego, opracowanie długofalowej strategii oraz schematów ewaluacyjnych. Dużą rolę odgrywało przygotowanie narzędzi do monitoringu, który ma dostarczyć danych do ewaluacji zmieniających się potrzeb oraz efektów realizacji strategii profilaktycznej. Dlatego też niezbędne było zapewnienie wsparcia badaczy. Doświadczenia tego projektu stanowią dobry punkt wyjścia do namysłu nad koncepcją wspólnych działań w społecznościach lokalnych krajów uczestniczących w seminarium.

Koncept wspólnych działań na poziomie lokalnym wypracowany w trakcie seminarium zakłada:

- opracowanie standardowego badania porównawczego na temat gotowości społeczności do podjęcia działań zapobiegawczych zwiazanych $z$ alkoholem i innymi substancjami psychoaktywnymi,

- opracowanie standardowego badania porównawczego dotyczacego używania alkoholu $i$ narkotyków przez młodzież i młodych dorostych,

- opracowanie narzędzi dla przemyślanej i opartej na dowodach polityki służacej zmniejszeniu obciążeń zdrowotnych zwiazanych $z$ używaiem alkoholu $i$ innych substancji psychoaktywnych oraz obciążen ekonomicznych,

- wzmocnienie potencjału administracji lokalnej, struktur instytucji zdrowia publicznego i organizacji młodzieżowych $w$ celu opracowania oraz wdrożenia skutecznych i trwałych działań profilaktycznych,

- wzmocnienie potencjału lokalnych instytucji wwykorzystaniu źródet danych do ustalenia celów $i$ zapewnienia ich realizacji oraz do analizowania zmian dotyczacych problemów zwiazanych $z$ alkoholem i substancjami psychoaktywnymi,

- budowanie wspólpracy międzyinstytucjonalnej $w$ celu skutecznego wdrażania działań zapobiegawczych na szczeblu lokalnym,

- stworzenie sieci centrów zdrowia publicznego w społecznościach lokalnych w Regionie Wymiaru 
The concept of common activities developed during the seminar is a starting point for the preparation of coordinated projects concentrating on supporting the prevention of psychoactive substance use at the local level. Applications are to be prepared for financing these projects from the next budget of the Norwegian Financial Mechanism.

In the longer term, cooperation in prevention and especially the preparation and realisation of coordinated projects is to result in the development of evidence based local preventive programmes that shall contribute to the limitation of problems associated with psychoactive substance use also in our country.
Pótnocnego i zwiększenie wspótpracy regionalnej $w$ zakresie działań profilaktycznych dotyczacych alkoholu i innych substancji psychoaktywnych,

- opracowanie raportu prezentującego przeglad poszczególnych profili krajowych.

Koncepcja wspólnych działań opracowana w czasie seminarium stanowi punkt wyjścia do przygotowania skoordynowanych projektów koncentrujących się na wspieraniu profilaktyki używania substancji na poziomie lokalnym. Na sfinansowanie tych projektów zostaną przygotowane wnioski o środki z następnej perspektywy finansowej Norweskiego Mechanizmu Finansowego.

W dłuższej perspektywie współpraca w zakresie profilaktyki, a w szczególności przygotowanie i realizacja skoordynowanych projektów, zaowocuje opracowaniem potwierdzonych empirycznie lokalnych programów profilaktycznych, które przyczynią się do ograniczenia problemów związanych z używaniem substancji psychoaktywnych także w naszym kraju.

\section{Conflict of interest/Konflikt interesów}

None declared./Nie występuje.

\section{Financial support/Finansowanie}

This report was financed by the Norwegian Bilateral Relation Fund in the frame of the Programme PL13 "Reducing social inequalities in health"./Opracowanie tekstu zostało sfinansowane z środków Norweskiego Funduszu Współpracy Dwustronnej w ramach Programu PL13 „Ograniczanie społecznych nierówności w zdrowiu”.

\section{Ethics/Etyka}

The work described in this article has been carried out in accordance with the Code of Ethics of the World Medical Association (Declaration of Helsinki) on medical research involving human subjects, EU Directive (210/63/EU) on protection of animals used for scientific purposes, Uniform Requirements for manuscripts submitted to biomedical journals and the ethical principles defined in the Farmington Consensus of 1997.

Treści przedstawione w pracy są zgodne z zasadami Deklaracji Helsińskiej odnoszącymi się do badań z udziałem ludzi, dyrektywami EU dotyczącymi ochrony zwierząt używanych do celów naukowych, ujednoliconymi wymaganiami dla czasopism biomedycznych oraz z zasadami etycznymi określonymi w Porozumieniu z Farmington w 1997 roku. 